\title{
Science for the sustainable use of ecosystem services [version
}

\section{1; peer review: 2 approved]}

\section{Elena M. Bennett ${ }^{1}$, Rebecca Chaplin-Kramer²}

${ }^{1}$ Department of Natural Resource Sciences and McGill School of Environment, McGill University, Ste-Anne-de-Bellevue, Canada

${ }^{2}$ Natural Capital Project, Stanford University, Stanford, USA

V1 First published: 02 Nov 2016, 5(F1000 Faculty Rev):2622

https://doi.org/10.12688/f1000research.9470.1

Latest published: 02 Nov 2016, 5(F1000 Faculty Rev):2622

https://doi.org/10.12688/f1000research.9470.1

\section{Abstract}

Sustainability is a key challenge for humanity in the 21st century. Ecosystem services-the benefits that people derive from nature and natural capital-is a concept often used to help explain human reliance on nature and frame the decisions we make in terms of the ongoing value of nature to human wellbeing. Yet ecosystem service science has not always lived up to the promise of its potential. Despite advances in the scientific literature, ecosystem service science has not yet answered some of the most critical questions posed by decisionmakers in the realm of sustainability. Here, we explore the history of ecosystem service science, discuss advances in conceptualization and measurement, and point toward further work needed to improve the use of ecosystem service in decisions about sustainable development.

\section{Keywords}

sustainable development, human wellbeing , human impact, conservation

\section{Open Peer Review \\ Approval Status \\ 1 \\ 2 \\ version 1 \\ 02 Nov 2016 \\ Faculty Reviews are review articles written by the prestigious Members of Faculty Opinions. The articles are commissioned and peer reviewed before publication to ensure that the final, published version is comprehensive and accessible. The reviewers who approved the final version are listed with their names and affiliations.

\footnotetext{
1. Brendan Fischer, University of Vermont, Burlington, USA

2. Liu Jianguo, Michigan State University, East Lansing, USA
}

Any comments on the article can be found at the end of the article. 
Corresponding author: Elena M. Bennett (elena.bennett@mcgill.ca)

Competing interests: The authors declare that they have no competing interests.

Grant information: EMB thanks the Natural Sciences and Engineering Research Council of Canada for an EWR Steacie Fellowship that helped provide funding and time to work on this article.

Copyright: ( 2016 Bennett EM and Chaplin-Kramer R. This is an open access article distributed under the terms of the Creative Commons Attribution License, which permits unrestricted use, distribution, and reproduction in any medium, provided the original work is properly cited. The author(s) is/are employees of the US Government and therefore domestic copyright protection in USA does not apply to this work. The work may be protected under the copyright laws of other jurisdictions when used in those jurisdictions.

How to cite this article: Bennett EM and Chaplin-Kramer R. Science for the sustainable use of ecosystem services [version 1; peer review: 2 approved] F1000Research 2016, 5(F1000 Faculty Rev):2622 https://doi.org/10.12688/f1000research.9470.1

First published: 02 Nov 2016, 5(F1000 Faculty Rev):2622 https://doi.org/10.12688/f1000research.9470.1 


\section{Introduction}

As human societies continue to transform the biosphere, sustainability - the ability for humans to continue to exist and even thrive on the planet-has emerged as a key challenge. Ecosystem services (ESs) - the benefits that people derive from nature and natural capital-is a concept often used to help explain human reliance on nature ${ }^{1}$ or to justify conservation actions ${ }^{2}$. At the same time, the use of ESs by people (for example, food, fresh water for drinking, and recreation) is a necessary part of improving human wellbeing (HWB) ${ }^{3}$, and some of those uses are consumptive, impacting future provision of the service or the continued provision of other services. This ultimately leads to a situation in which society must determine how best to use ESs to improve HWB now while working to ensure that ESs will be provided equitably now and for future generations. This article examines the state of the science of ESs and considers what more we still need to learn to help ensure that ESs are being used sustainably.

The concept of ESs has become hugely popular, in part because it frames the decisions we make affecting nature in terms of the value of nature to people (including values beyond monetization) and makes those values more visible ${ }^{4,5}$. The ES concept also has the potential to bring together issues of sustainability and environment with those of international development, which has been discussed for quite some time in the environment and development literatures but has proven difficult to achieve $e^{6,7}$. ESs are also quantifiable, and differences in their provision thus can be related to biophysical or ecological aspects of landscapes, to land use and management decisions, or to changes in values, individual preferences, and social demand, making the concept ideal for those who aim to improve conservation while taking development into consideration.

Yet, over the years, there have been many articles criticizing the ES concept or wondering why the concept and data about ESs have not led to more sweeping changes to decision-making ${ }^{2,8-10}$. Indeed, despite considerable advancement in this field over the past few decades, ES science is still not answering some of the most critical questions posed by decision-makers in the realm of sustainability (Table 1). In this article, we explore the history of ESs, discuss advances in conceptualization and measurement, and point toward advances needed to improve the use of ES in decisions about sustainable development.

\section{Ecosystem services and sustainability science: key steps forward}

Grappling with the human impact on the environment is not new; in some ways, the conversation about people, nature, and conservation is centuries old (for example, 11, 12). Yet the conversation has changed over time. Mace ${ }^{13}$ showed how the framing of the conversation has shifted from a conservation that prioritized wilderness (1960s and before) to one that focused on threats to habitats (1970s and 1980s) to the emergence of ESs in the 1990s as a way to reveal the importance of nature to HWB and finally (currently) to a nuanced perspective that recognizes the complex, dynamic relationships between people and nature.

Throughout this conceptual evolution, scientists have weighed in on the importance of ecosystem process and function to the "life-support system" of earth and the role of conservation in maintaining this life-support system. The first use of the term "ecosystem services", by Ehrlich and Ehrlich ${ }^{14}$, actually built off an even earlier reference to "environmental services"15, as Ehrlich himself later attributed ${ }^{16}$. The Study of Critical Environmental Problems ${ }^{15}$ provided examples of the functions and processes performed by ecosystems that are essential to life as we know it: pest control, pollination, soil retention, soil formation, nutrient cycling, atmospheric and climate regulation, flood control, and fisheries. Missing from this list are some of the benefits that resonate most with people today: water provision and purification, timber production and non-timber forest products, recreation and ecotourism opportunities, forage production, and crop production. Many of these latter services are the so-called final services that are directly relevant to people, the production of which the initially defined list of services plays a critical role in supporting.

Early ecological literature on ESs continued to focus on the supporting services (for example, 17), which echoed the familiarto-ecologists ecosystem processes but which often stopped just short of articulating the direct benefit to people, whereas the economics literature at the time sought to value nature in terms of its utility to humans as a way of internalizing externalities ${ }^{18}$. When society bears the cost (the externality) of an activity that degrades an ecosystem for private benefit, it is difficult to incentivize (internalize) more sustainable behavior without an adequate accounting for the full cost of that degradation. The main challenge economists were beginning to grapple with in valuing nature by around the turn of the century was that the whole was greater than they could express through summing the parts; available methods for price setting and valuation focused on small (marginal) changes, while it was well understood that the life-support system provided by nature was priceless ${ }^{19}$. So the question for economists became the impact of intermediate change, especially when an intermediate amount of change can intersect an ecological threshold that pushes the system into a new state, resulting in fairly small ecological changes that can lead to significant impact on the long-term provision of $\mathrm{ESs}^{20-22}$.

The soaring popularity of ESs really emerged in the ecological literature by the late $1990 \mathrm{~s}^{1}$, at which point the first hint of cultural values for ESs ("support of diverse human cultures" and "providing of aesthetic beauty and intellectual stimulation that lift the human spirit" $)^{1}$ were added to a conceptualization of services that was still very much oriented toward ecosystem functions, at least in the ecological literature (much of the environmental economics literature had picked up on these issues earlier but typically without the ecological function orientation). As the list of recognized ESs grew longer and more directly connected to $\mathrm{HWB}^{3,23}$, the relevance of the concept to policy and decision at a variety of levels became evident. Fundamentally, the concept of ESs grew out of a time when nature was ignored by many facets of human enterprise and scientists and conservationists desired a way to highlight the value of nature to society.

\section{Frameworks for assessing ecosystem services}

Around the turn of the century, scientists identified the need for an international assessment of ESs. The idea was to develop something akin to the Intergovernmental Panel on Climate Change but for ecosystems, taking advantage of recent advances in 
ecological and other sciences in the 1990s and putting this knowledge in the hands of international policy-makers ${ }^{24}$. Ultimately, this became the Millennium Ecosystem Assessment (MA). The MA developed an ES framework that reflected the thinking of the time, showing a relationship between ESs (left side of Figure 1) and HWB (right side of Figure 1); arrows generally flowed from ecosystems and their services toward wellbeing, and the focus was on understanding the intensity of linkages and the potential for mediation of the relationship ${ }^{3,23}$.

In an update conceived by de Groot et al. ${ }^{5}$ and based on the cascade model of Haines-Young and Potschin ${ }^{25}$, the MA framework is broken down into more of its constituent parts (Figure 2). Here, ecosystem structure and functions (that occupy much of the early thinking on ESs noted in the previous section) support the provision of a service, which is the actual benefit of nature to people. Breaking down the concept into these parts helps to gain clarity on how services are provided by nature, allowing the ecosystem to become multi-faceted and complex in our understanding. De Groot et al. ${ }^{5}$ have added here the idea of feedbacks from HWB to both ESs and ecosystems, indicating that people can alter ecosystems and the services provided on the basis of their desires or differences between their perception of services provided and services required. Although we know that people are critical players in the delivery of ESs - plowing, fertilizing, seed planting, and harvesting are needed to produce food, even if there is already good natural capital (for example, high-quality soils) in placethe primary idea of even this new framework is that ecosystems alone ultimately provide services to people. That is, there is a general and primary flow from the left (ecosystems) to the right (people), and feedbacks are from the people to the ecosystem.

This rather linear conceptualization of ESs was given another significant update ${ }^{26}$ (Figure 3), including a diagram in which it is not "nature" but social-ecological systems (nature and people together), which generate bundles of services (multiple services together), which impact various dimensions of HWB. HWB, in turn, affects management and governance. In this framework, the social system plays a critical role not only in demanding and receiving ESs but also in determining their provision. This is significant because it emphasizes the role of society in the provision of services, moving the ES conversation to the more nuanced depiction of dynamic human-nature relationships ${ }^{13,27,28}$. Also critical in this framework is the explicit consideration of ES bundles

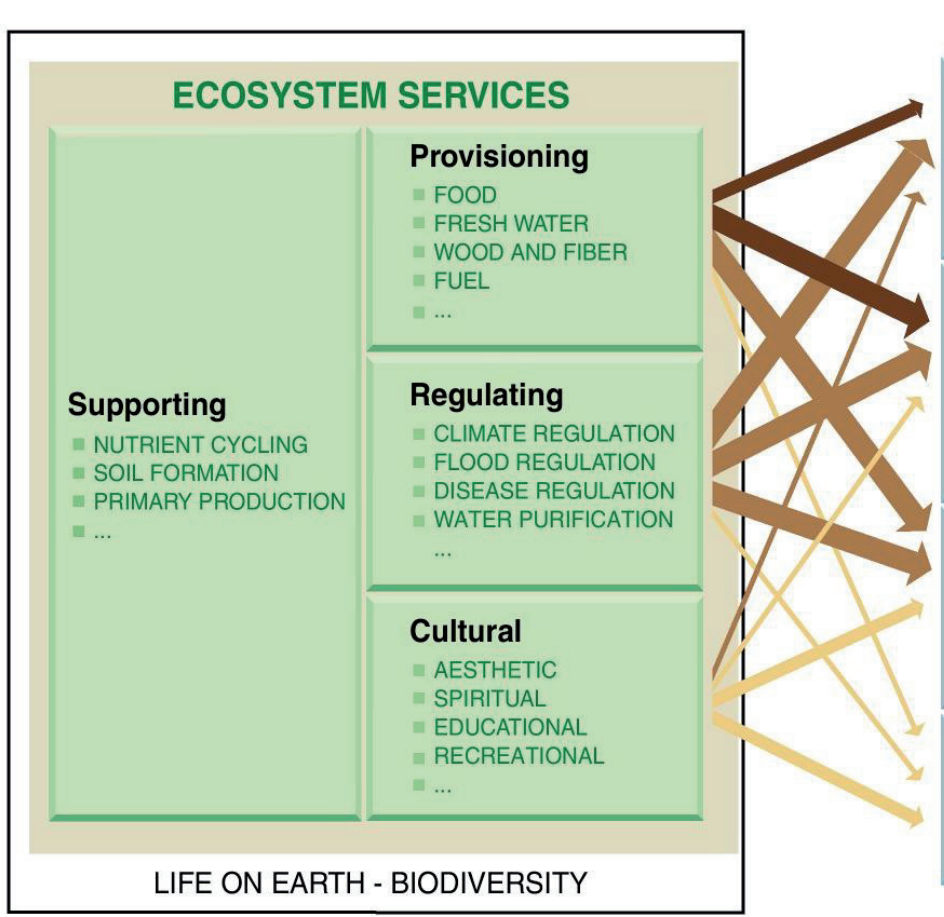

ARROW'S COLOR Potential for mediation by socioeconomic factors

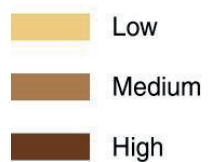

\section{ARROW'S WIDTH}

Intensity of linkages between ecosystem

services and human well-being

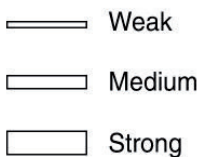

\section{CONSTITUENTS OF WELL-BEING}

\section{Security}

- PERSONAL SAFETY

- SECURE RESOURCE ACCESS

= SECURITY FROM DISASTERS

\section{Basic material}

for good life

ADEQUATE LIVELIHOODS

- SUFFICIENT NUTRITIOUS FOOD

$=$ SHELTER

- ACCESS TO GOODS

\section{Health}

= STRENGTH

- FEELING WELL

- ACCESS TO CLEAN AIR

AND WATER

\section{Good social relations}

- SOCIAL COHESION

MUTUAL RESPECT

- ABILITY TO HELP OTHERS

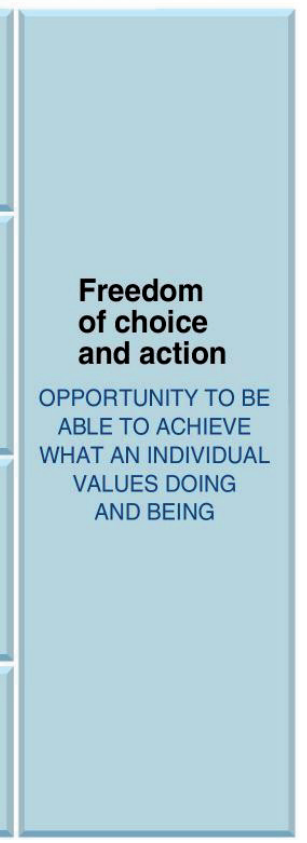

Source: Millennium Ecosystem Assessment

Figure 1. The Framework of the Millennium Ecosystem Assessment (2002). Reproduced from the Millenium Ecosystem Assessment (2002). 


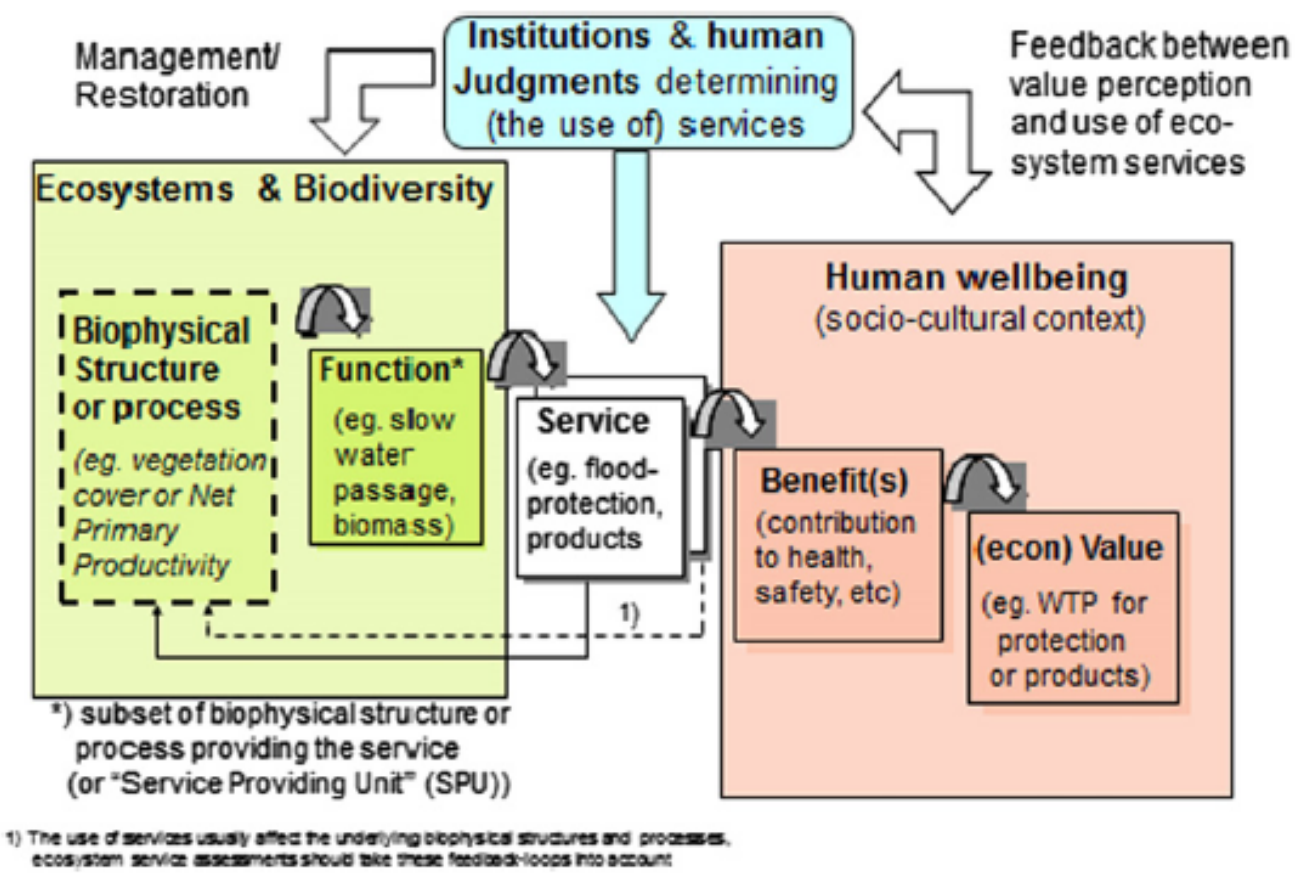

Figure 2. The Economics of Ecosystems and Biodiversity Framework. WTP, willingness to pay. Reproduced from Braat and de Groot ${ }^{78}$ (2012), adapted from Haines-Young and Potschin ${ }^{25}$ (2010).

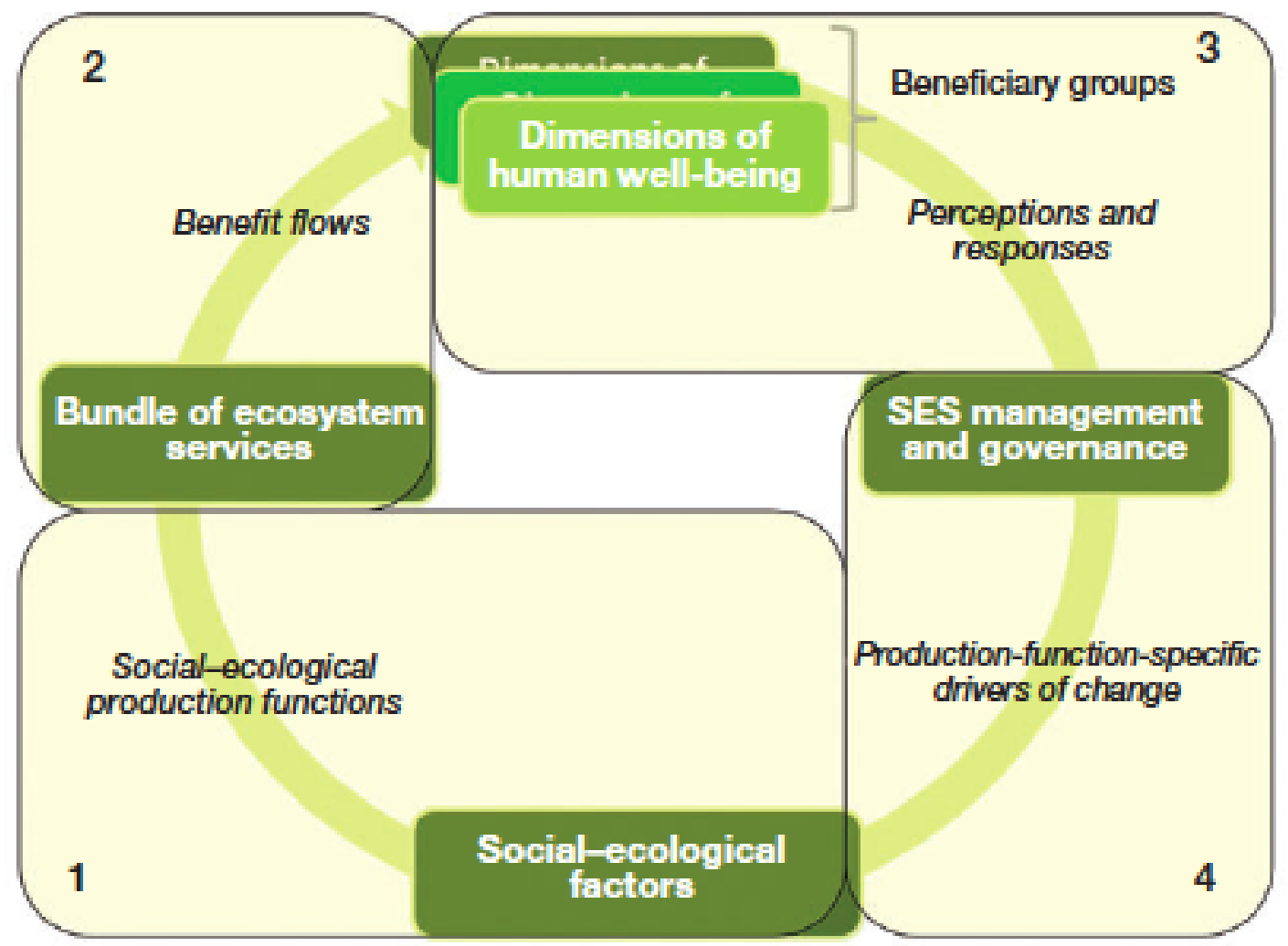

Figure 3. A social-ecological framework for ecosystem service and human wellbeing. SES, social-ecological systems. Reprinted with permission from Reyers et al. ${ }^{26}$ (2013). 
rather than single services. Other non-linear frameworks have been proposed. For example, Liu et al. ${ }^{29}$ note that telecoupling (socioeconomic and environmental interactions between different places) is increasingly important in the Anthropocene and ought to be included in the way we understand and measure ESs.

\section{Advances in mapping and measuring multiple services}

Beyond frameworks, the past decade has also brought considerable advances in measuring ESs and using these measurements as tools in decision-making. One of the most critical and basic advancements brought about by ES science is the focus on the ways that we use ecosystems (actively and passively) to ensure $\mathrm{HWB}^{28}$ and the (direct and indirect) contribution of ecosystems to $\mathrm{HWB}^{30,31}$. A major challenge in this has been in approaching the science of ESs as holistically as the concept implies, especially in terms of interactions between multiple services, spatial dynamics, and change over time.

Although some early articles focused on mapping multiple ESs to understand associations among services ${ }^{32}$ or among multiple services and biodiversity (for example, 33, 34), much of the ES literature has failed to live up to the promise of ESs to link nature and HWB, or to consider all aspects of sustainability, and a great many articles examine only one service, measure services at a single time snapshot, or measure ecosystem function with little or no connection to $\mathrm{HWB}^{35}$. By contrast, decision-makers most often need information about multiple services and how they affect outcomes for people in order to make decisions that improve longterm sustainability ${ }^{5}$. When the goal is to use ESs to improve sustainable development, considering multiple services over time is critical because any decision is likely to result in trade-offs, in which increases in some services lead to or are associated with declines in production of other services ${ }^{36}$.

However, there are examples of ES studies that have focused on multiple services and sometimes on linking these to potential decisions or to HWB. For example, Bateman et al. ${ }^{37}$ highlight the UK National Ecosystem Assessment, which combined spatially explicit ecological models with economic valuation to assess ESs and improve land use planning in the UK. Scientists have looked for areas that are hot spots of high provision of multiple services and understanding what creates these win-wins (for example, 32-34). Qiu and Turner ${ }^{38}$, for example, found that, although most relationships among ESs were synergies, hot spots (locations where at least six services were produced at high levels) were quite rare, occupying just $3.3 \%$ of the landscape. These authors also found that trade-offs were not consistent across space. That is, whereas most locations had a trade-off between crop production and water quality, some locations had both high water quality and high crop production, suggesting that this trade-off is not inevitable or that it might be able to be ameliorated. This study not only provided specific data about ES provision in a particular place for decisionmakers in that region but also developed some generalizable knowledge, such as that managing ESs over large areas is likely to improve our ability to manage for sustainable provision of services $^{38}$.
A recent development in ES sciences is the movement from studies of single services or pairs of services to studies that focus on bundles of ESs, associations of several ESs that appear together repeatedly in space or time. Queiroz et al. ${ }^{39}$ identified five distinct types of ES bundles in Sweden: "forests and towns", "remote forest", "mosaic cropland-livestock", "mosaic cropland-horse", and "urban". They found that the production of an ES or ES bundle was based on a combination of the social-ecological potential (ecological and biophysical conditions and management practices) of a landscape to produce it and the human demand for that same service. In this as in many studies on ES bundles, hot spots of provisioning service production are often cold spots for regulating services. Thus, it is increasingly apparent that both ecological and social gradients are needed to adequately predict patterns of ES provision across landscapes ${ }^{40-45}$.

In addition to understanding how social-ecological landscapes provide ES bundles, progress has been made in refining the idea of trade-offs among pairs of services. Mouchet et al. ${ }^{46}$ suggest that there are three types of trade-off assessments. Supply-supply assessments are about how supply of one service affects supply of another; supply-demand assessments are about whether the ecosystem can meet demand; and demand-demand assessments are about stakeholders' competing interests. The method the authors propose takes a step toward embracing social-ecological systems and complexity in considering both supply and demand as well as their interactions. The importance of understanding the difference between supply, demand, and ecosystem capacity to provide services was also highlighted by Villamagna et al. ${ }^{47}$, who pointed out that it is the comparison of supply with demand in the current time that determines satisfaction with the services provided and that it is the comparison of capacity with supply that determines the potential for sustainability.

Another advance in measuring and mapping ESs has been work to understand the role of landscape structure - the configuration of land use and land cover-in the provision of services. This is important for landscape management, especially over large areas, as suggested by Qiu and Turner, as the structure of the landscape is something that land use planners can influence with reasonable precision. Different spatial patterns of land use and cover may benefit different services, and trade-offs between services can be mitigated or exacerbated by fragmentation at different scales ${ }^{48,49}$. Landscape complexity, measured in terms of the proportion or diversity of natural habitat or its arrangement in the areas surrounding agriculture or both, enhances the pollination of crops ${ }^{50}$ and pest control by natural predators ${ }^{51}$ in a variety of cropping systems and regions ${ }^{52}$. For these mobile organisms benefitting cropland, increasing interface between human and natural systems generally increases service provision, assuming an adequate ratio of natural to agricultural habitat. Other services may be reduced by this type of natural-agricultural mosaic; ChaplinKramer et al..$^{53}$ demonstrate that forest fragmentation reduces carbon sequestration by an average of $25 \%$ across the tropics. Whereas previous studies had estimated carbon sequestration on the basis of a benefits-transfer approach that assumes a direct 
relationship between forest area and carbon storage, the study by Chaplin-Kramer et al. shows that the configuration of the land use, and especially the amount of forest edge created by deforestation, makes a difference to the amount of service provided. Studies of carbon storage in temperate forests also find important effects of both spatial structure and human management ${ }^{54}$. For water-related services, the aspect of landscape configuration that matters most is hydrologic connectivity to water courses ${ }^{55}$, which presents yet another type of spatial habitat pattern to consider in managing for multi-functional landscapes.

Although many ES studies have been snapshots of service provision at a single moment in time, it is widely acknowledged that ESs and their relationships with each other, and with the drivers that affect their supply, are unlikely to remain constant over time ${ }^{46}$. Recent studies have begun to examine how changes in landscapes over time have affected the provision of services. Renard et al. ${ }^{56}$ found that some individual service relationships varied through time, shifting from trade-offs or no relationship at the start of the study (1971) to synergies by the end (2006). In terms of bundles, in 1971, the landscape was diverse, but most municipalities across the landscape were all providing similar bundles; by 2006, the landscape remained fairly diverse, but each municipality tended to specialize in the provision of one or a few services.

Finally, mapping and measuring ESs have been and will continue to be critical methods for understanding past trends and anticipating future trajectories and for evaluating the impact of policy interventions and whether goals are being met. However, many decisions require more information than can be gleaned from examining changes that have already occurred; policy-makers and other incentive setters wishing to promote the sustainable use of ESs have questions about where the most important places are to invest in conservation or restoration, what the impacts of allowing different types of development will be for different stakeholders, or how to most cost-effectively mitigate those impacts (Table 1). In many cases, measuring ESs on the ground in specific places has led to empirical models that can inform decision-makers in those regions ${ }^{48,57}$. For example, work by Fisher et al. ${ }^{58}$ focused on understanding the various benefits of reducing deforestation in Tanzania.

\section{Including people, governance, and resilience}

These improvements in scientists' ability to map, measure, and model individual ESs, pairs of ESs, and bundles of ESs have led to discussions about how ES science could be used to improve ecosystem management or to understand and assess progress toward policy targets such as the Sustainable Development Goals. However, actual use of ES science in decision-making has sometimes fallen short of expectations ${ }^{2,59,60}$. Carpenter et al. ${ }^{9}$ suggest that part of the problem may be a discipline-bound focus of some of the science as well as failure to consider feedbacks over a range of biophysical and social systems. Reyers et al. ${ }^{26}$ propose that, in the rush to gather data, science has found itself with a plethora of measures that fall short of their intended purpose. That is, we have lots of measurements, but these use conflicting definitions or poor indicators, which makes use of ESs to assess targets like the Sustainable Development Goals difficult at best. Newer studies are advancing rapidly in developing multiple ES-based methods for assessing the effect of policy interventions on sustainability. For example, Hamann et al. ${ }^{61}$ developed and tested an approach to mapping social-ecological systems on the basis of characteristic bundles of ES use. The idea was that these bundles ultimately could be used as a tool to identify different socialecological system types and target governance interventions more appropriately.

One outcome of the focus on social-ecological systems has been increased interest in HWB and in co-design of research projects with stakeholders, research that actively involves decision-makers to improve uptake and use of information in decision-making ${ }^{62}$. Cundill and Fabricius ${ }^{63}$ suggest that although there is a wealth of frameworks for understanding complex systems, relatively less attention has been given to co-design and other approaches that might facilitate learning as part of the monitoring process. Such co-design is important because it can help ensure that science is both interesting to the scientific community and useful to decision-makers ${ }^{64}$. This helps mainstream ESs as a part of decision-making. Similarly, researchers are now pointing out the need to include more nuanced, quantitative analyses of ESs and $\mathrm{HWB}^{65}$ and even developing indices to understand when and how wellbeing depends on provision of services ${ }^{66}$. Ultimately, if decision-makers are concerned with the wellbeing of constituents or stakeholders, research that goes only as far as the biophysical components of services may be less useful than work that quantifies HWB outcomes or seeks to understand relationships between services and wellbeing.

Including social-ecological systems has also paved the way to merge concepts of resilience with ESs, a significant step forward in moving ES science to a place where it can improve ecosystem management for sustainability. Extensive anthropogenic changes, mostly to provide certain ESs such as food, have increased the likelihood of large, non-linear, and possibly irreversible changes in ecosystems ${ }^{67,68}$. Recognizing that enhancing ES resilience is crucial for meeting current and future societal needs, Biggs et $a l .{ }^{69}$ use the literature to suggest seven principles for enhancing the resilience of ESs in social-ecological systems: maintain diversity and redundancy, manage connectivity, manage slow variables and feedbacks, foster an understanding of social-ecological systems as complex adaptive systems, encourage learning and experimentation, broaden participation, and promote polycentric governance systems. Developing this definitive set of resilienceenhancing principles for ESs and a synthetic understanding of when and where they apply is important for those in the governance arena seeking to ensure a sustainable provision of services for the long term while avoiding large, non-linear changes in service provision, which can have catastrophic effects on HWB.

\section{Continuing issues}

Several countries, including the UK, China, and South Africa, have undertaken national ecosystem assessments ${ }^{37,70-72}$, which are an important step toward measuring and monitoring change in ESs on a large scale. Findings from such efforts are being translated to diverse contexts in many other countries through international collaborations such as the Intergovernmental Panel on Biodiversity and Ecosystem Services (IPBES) or the Group on Earth 
Observations-Biodiversity Observation Network (GEOBON). Experimental accounting methods-for example, promoted by the Wealth Accounting and Valuation of Ecosystem Services (WAVES) program - at institutions like the World Bank aim to transform national accounts to reflect ES values in countries' financial ledgers. However, most of these examples are focused on assessing current baselines or past trends, and although this is an important first step to integrating ES into decisions, it does not provide action-ready and easily digestible information about the consequences of any particular land, ocean, or natural resource use decision. Although regional and national ecological and economic assessments are helpful, they do not typically help mainstream the type of decision support that is now needed across scales.

Furthermore, although models exist for including ES in a costbenefit analysis or return-on-investment calculation, too often models are not accessible enough at the time they are needed, or data are not available to complete them, with the result that ESs are often left out of environmental impact reports or development or zoning plans. Part of this is due to a failure on the part of the scientific community to standardize data and approaches in forms that could be used by agency staff or consulting groups they contract to make it standard practice. In a promising new development, the US has recently mandated all federal agencies to consider how ESs could be included in their planning ${ }^{73}$, and with some trial and error this may help to better articulate what form such standard approaches should take.

Additionally, despite advances, many gaps remain in our understanding of the ecology of ESs, some of which were already recognized more than a decade ago $^{74}$, and the field still faces multiple challenges: a fairly discipline-bound science $^{9}$, limited involvement of stakeholders in the development of the questions that guide many scientific studies ${ }^{75}$, and confusion about the multiple potential indicators available for measuring $\mathrm{ESs}^{76}$. For these and perhaps other reasons, ES science has not been fully adopted by decision-makers and has not reached the full potential of socio-ecological integration it is intended to promote pr. $^{77}$.

One of the original agendas of ES researchers was to bring together natural science and economics, conservation, and development ${ }^{78}$. Although conceptually ESs seemed poised to make this happen, ES researchers have not yet been entirely successful. Many efforts remain bound by disciplinary boundaries. This may be, in part, because the types of questions that are interesting differ among disciplines in ways that present significant barriers to funding and publishing.

Involving stakeholders in question development, and sometimes in the scientific process of answering those questions, may also hold important keys for improving the use of ES science in decision-making. In fact, it is so important that some have found that stakeholder involvement in ES research is a better predictor of policy change than the nature of the findings themselves ${ }^{79}$. This may be because one benefit of co-designed science is the trust that is built between scientists and decision-makers ${ }^{80}$ or because it encourages scientists to work at the scale at which decisions are being made $^{81}$.
There also remains considerable confusion in the use of terms, especially in the use of indicators. The difference between ecosystem process, function, and service remains muddled, and some scientists use these terms interchangeably whereas others make clear distinctions. Liss et al. ${ }^{76}$ surveyed the literature on pollination as an ES and found that, in 121 studies that self-identified as being about both ESs and pollination, 62 unique metrics were used to assess the amount of pollination. The authors showed how these inconsistent measurements complicate attempts at comparison or synthesis and can even lead to very different management decisions.

Ultimately, many are finding that, for a variety of reasons, ecology as it stands is limited in its predictive capacity to identify the sustainable use of any particular ES and to describe the trade-offs between uses of $\mathrm{ESs}^{82-84}$. Moving from one ecosystem to another or, better yet, developing general principles ${ }^{4}$ has been difficult ${ }^{85}$. Some general principles emerging from this work are beginning to be included in broadly accessible, globally applicable tools for decision support and scenario analysis, such as Integrated Valuation of Ecosystem Services and Tradeoffs (InVEST) ${ }^{86}$, Artificial Intelligence for Ecosystem Services (ARIES) ${ }^{87}$, and others ${ }^{88,89}$ (see 90 for a review of these tools). The goal of these tools is to improve access of decision-makers to the latest ES knowledge in an easily digestible format that allows better integration of ESs into decisions affecting the sustainable use and provision of ESs in the future. However, these tools are still challenged by data constraints for model parameterization and calibration to make them fully accessible and accurate and are lacking representation of key components (for example, threshold effects) or services (especially cultural). That is, it is still difficult to know, for any particular land use or management decision, the outcomes in both the short and long term for a full set of relevant ESs. And although we do have the ability to determine this with scads of research in a particular location, this often takes longer than the time frame in which the decision must be made. Thus, the ES concept has proven useful in moving forward thinking, but the science has not been sufficiently predictive to support full application of the concept in decisionmaking for sustainability.

Despite such limitations, from a value-of-information perspective, the knowledge of ESs we are currently capable of representing is adequate for informing many types of decisions, including spatial targeting of best management practices ${ }^{91,92}$ or restoration opportunities ${ }^{93}$, understanding equity implications of development impacts ${ }^{94}$, and identifying where green infrastructure has the potential to support or enhance grey infrastructure ${ }^{95}$. Although many unanswered questions remain in defining and planning for truly sustainable development, we can learn from implementing policies based on the science we do have, tracking outcomes, and adaptively managing for improvement ${ }^{96,97}$.

\section{Future directions}

For ESs to contribute to enhancing the sustainability of the human enterprise, ES science must move beyond conceptualizing and mapping and into addressing the difficult, complex questions that have dogged sustainability science for decades. Based on the review of the literature here, we propose a handful of critical future directions for ES science (Table 1). 
Table 1. Future directions in ecosystem service science and their importance.

\begin{tabular}{|c|c|c|c|c|}
\hline Future direction & $\begin{array}{l}\text { Key question asked by } \\
\text { decision-maker }\end{array}$ & Why it is important & How it could be done & $\begin{array}{l}\text { Example } \\
\text { citations }\end{array}$ \\
\hline \multicolumn{5}{|c|}{ Future directions in the long term } \\
\hline $\begin{array}{l}\text { Focus on ecosystem } \\
\text { service (ES) provision over } \\
\text { longer time frames. }\end{array}$ & $\begin{array}{l}\text { How will decisions made now } \\
\text { play out in terms of ES and } \\
\text { human wellbeing (HWB) now, } \\
\text { in } 10 \text { years, and in } 100 \text { years? }\end{array}$ & $\begin{array}{l}\text { Sustainability is about } \\
\text { the long term; snapshot } \\
\text { measures of ESs are of } \\
\text { limited benefit for assessing } \\
\text { sustainability. }\end{array}$ & $\begin{array}{l}\text { Integration of models of } \\
\text { climate and other drivers } \\
\text { of long-term change } \\
\text { and ES outcomes. Use } \\
\text { existing historical data. }\end{array}$ & 98,99 \\
\hline $\begin{array}{l}\text { Understand the role of path } \\
\text { dependency and legacies } \\
\text { in the provision of ESs. }\end{array}$ & $\begin{array}{l}\text { How will decisions made now } \\
\text { constrain future ES provision, } \\
\text { even if different or better } \\
\text { decisions are made later? }\end{array}$ & $\begin{array}{l}\text { Current land use may } \\
\text { create legacies that affect } \\
\text { future ES provision because } \\
\text { of path dependencies. }\end{array}$ & $\begin{array}{l}\text { Study role of past land } \\
\text { use in provision of } \\
\text { services today. }\end{array}$ & 56,100 \\
\hline $\begin{array}{l}\text { Plan for sustainable use } \\
\text { of ESs in a changing-not } \\
\text { static-world. }\end{array}$ & $\begin{array}{l}\text { How will climate change or } \\
\text { global economic change } \\
\text { affect the ES outcomes of land } \\
\text { use decisions? }\end{array}$ & $\begin{array}{l}\text { Climate, diets, } \\
\text { biogeochemical cycles, } \\
\text { increasing prevalence of } \\
\text { plastics-we know the } \\
\text { world is changing. }\end{array}$ & $\begin{array}{l}\text { Uncertainty analysis of } \\
\text { different scenarios of } \\
\text { change for more robust } \\
\text { decision-making }\end{array}$ & 29 \\
\hline \multicolumn{5}{|c|}{ Future directions of sustainable social-ecological systems } \\
\hline $\begin{array}{l}\text { Understand implications of } \\
\text { ES provision for HWB. }\end{array}$ & $\begin{array}{l}\text { How will livelihoods, human } \\
\text { health, or HWB be impacted } \\
\text { by a change in ES resulting } \\
\text { from a decision (and which } \\
\text { ESs are the critical ones to } \\
\text { consider)? }\end{array}$ & $\begin{array}{l}\text { The relationships between } \\
\text { ESs and HWB are often } \\
\text { as complex as (or more } \\
\text { complex than) the } \\
\text { relationships between } \\
\text { ecosystems and ESs, and } \\
\text { better understanding of } \\
\text { these linkages is needed. }\end{array}$ & $\begin{array}{l}\text { Better integration of } \\
\text { ES science with other } \\
\text { disciplines: development } \\
\text { economics, public } \\
\text { health, psychology, and } \\
\text { sociology }\end{array}$ & 65,66 \\
\hline $\begin{array}{l}\text { Understand the role of } \\
\text { multiple forms of capital } \\
\text { in the provision of ES and } \\
\text { HWB. }\end{array}$ & $\begin{array}{l}\text { When can various forms of } \\
\text { human capital substitute for } \\
\text { natural capital in the provision } \\
\text { of ES (and when can it not)? }\end{array}$ & $\begin{array}{l}\text { It is difficult to know how } \\
\text { important natural capital } \\
\text { is without comparing its } \\
\text { importance in service } \\
\text { provision with other } \\
\text { capitals. }\end{array}$ & $\begin{array}{l}\text { Build models that } \\
\text { estimate the role of } \\
\text { multiple forms of capital } \\
\text { in the provision of ESs. }\end{array}$ & 60 \\
\hline $\begin{array}{l}\text { Understand the function } \\
\text { of social ecological } \\
\text { systems in the provision of } \\
\text { ESs, their resilience, and } \\
\text { distribution. }\end{array}$ & $\begin{array}{l}\text { How do decisions to build } \\
\text { up or compromise different } \\
\text { sources of capital affect the } \\
\text { resilience of ES provision and } \\
\text { HWB in the long term? }\end{array}$ & $\begin{array}{l}\text { ESs are provided by social- } \\
\text { ecological systems, not } \\
\text { ecosystems alone. Leaving } \\
\text { out the social system will } \\
\text { result in incomplete or } \\
\text { incorrect answers to our } \\
\text { pressing questions. }\end{array}$ & $\begin{array}{l}\text { Expand system } \\
\text { boundaries of ES studies } \\
\text { to include social systems } \\
\text { in addition to ecological } \\
\text { ones. }\end{array}$ & 26,43 \\
\hline $\begin{array}{l}\text { Understand the role of } \\
\text { teleconnections and trade } \\
\text { in the provision of ESs and } \\
\text { HWB. }\end{array}$ & $\begin{array}{l}\text { When can ESs be purchased } \\
\text { from elsewhere (for example, } \\
\text { through international trade) } \\
\text { and when must they be locally } \\
\text { produced? }\end{array}$ & $\begin{array}{l}\text { Trade is an increasingly } \\
\text { important part of ecosystem } \\
\text { function in a globalized } \\
\text { world. }\end{array}$ & $\begin{array}{l}\text { Expand system } \\
\text { boundaries of ES studies } \\
\text { to include traded goods. }\end{array}$ & 101,102 \\
\hline \multicolumn{5}{|c|}{ Future directions of decision-relevant information } \\
\hline $\begin{array}{l}\text { Measure and monitor ES } \\
\text { governance and outcomes. }\end{array}$ & \multirow{3}{*}{$\begin{array}{l}\text { In order to answer the above } \\
\text { examples of decision-maker } \\
\text { questions, the science needs } \\
\text { to be co-developed with } \\
\text { practitioners and decision- } \\
\text { makers, to be measured } \\
\text { in a way that matters to } \\
\text { people and that resonates for } \\
\text { decisions, and to be tracked } \\
\text { over time so we can continue } \\
\text { to learn together and adapt } \\
\text { our future questions and } \\
\text { research. }\end{array}$} & $\begin{array}{l}\text { Information is limited, so } \\
\text { we must proceed with what } \\
\text { we do know and measure } \\
\text { effectiveness to adapt. }\end{array}$ & $\begin{array}{l}\text { Funding for monitoring } \\
\text { of both ecological and } \\
\text { social outcomes as an } \\
\text { integral part of policy } \\
\text { implementation }\end{array}$ & 64 \\
\hline $\begin{array}{l}\text { More co-designed } \\
\text { research, working with } \\
\text { stakeholders from the start }\end{array}$ & & $\begin{array}{l}\text { Science will be more } \\
\text { relevant to decisions and } \\
\text { more easily adopted if } \\
\text { stakeholders are involved. }\end{array}$ & $\begin{array}{l}\text { Create incentives in } \\
\text { academia for engaging } \\
\text { decision-makers and } \\
\text { create opportunities in } \\
\text { policy for approaching } \\
\text { management as an } \\
\text { experiment. }\end{array}$ & 79,103 \\
\hline $\begin{array}{l}\text { Improve understanding of } \\
\text { indicators and clearer use } \\
\text { of them. }\end{array}$ & & $\begin{array}{l}\text { Decision-makers need } \\
\text { simple metrics to track } \\
\text { progress and trends, even } \\
\text { where data are scarce. }\end{array}$ & $\begin{array}{l}\text { Explain the choice of } \\
\text { indicator, rationale, and } \\
\text { alternatives. }\end{array}$ & 76 \\
\hline
\end{tabular}


The future directions we suggest include many that effectively expand the boundaries of ES research in several directions. We suggest that ES science consider longer time frames and include ongoing global change, non-linearities, and uncertainty in this analysis. ES science should also expand its disciplinary boundaries to include information about multiple forms of capital and the role of social systems in demand for, and provision of, services and include stakeholders in design and even implementation of some research plans. Expanding physical boundaries to include the role of trade in moving some types of services around the planet will also be a critical next step in understanding planetary ES provision and its implications for sustainability.

ES science holds great promise to help society assess progress toward meeting planetary sustainability and development goals such as the Sustainable Development Goals. To fully achieve that potential and to answer the most important questions decision-makers are asking, the science must continue to develop beyond disciplinary boundaries to consider the long-term provision of ESs by social-ecological systems.

\section{Abbreviations}

ES, ecosystem service; HWB, human wellbeing; MA, Millennium Ecosystem Assessment.

\section{Competing interests}

The authors declare that they have no competing interests.

\section{Grant information}

EMB thanks the Natural Sciences and Engineering Research Council of Canada for an EWR Steacie Fellowship that helped provide funding and time to work on this article.
1. Daily GC: Nature's Services: Societal Dependence On Natural Ecosystems. Island Press, 1997.

Reference Source

2. F Guerry AD, Polasky S, Lubchenco J, et al:: Natural capital and ecosystem services informing decisions: From promise to practice. Proc Natl Acad Sci U S A. 2015; 112(24): 7348-55.

PubMed Abstract | Publisher Full Text | Free Full Text | F1000 Recommendation

3. Millennium Ecosystem Assessment: Ecosystems and Human Well-being: Synthesis for Decision-Makers. Washington, DC: Island Press, 2005. Reference Source

4. Daily GC, Söderqvist T, Aniyar S, et al.: Ecology. The value of nature and the nature of value. Science. 2000; 289(5478): 395-6. PubMed Abstract | Publisher Full Text

5. $\quad \mathrm{F}$ de Groot RS, Alkemade R, Braat L, et al:: Challenges in integrating the concept of ecosystem services and values in landscape planning, management and decision making. Ecol Complexity. 2010; 7(3): 260-72. Publisher Full Text | F1000 Recommendation

6. F Griggs D, Stafford-Smith M, Gaffney O, et al.: Policy: Sustainable development goals for people and planet. Nature. 2013; 495(7441): 305-7. PubMed Abstract | Publisher Full Text | F1000 Recommendation

7. F Wood SLR, DeClerck F: Ecosystems and human well-being in the Sustainable Development Goals. Front Ecol Environ. 2015; 13(3): 123. Publisher Full Text | F1000 Recommendation

8. F Norgaard RB: Ecosystem services: From eye-opening metaphor to complexity blinder. Ecol Econ. 2010; 69(6): 1219-27. Publisher Full Text | F1000 Recommendation

9. Carpenter SR, Mooney HA, Agard J, et al:: Science for managing ecosystem services: Beyond the Millennium Ecosystem Assessment. Proc Natl Acad Sci U S A. 2009; 106(5): 1305-12.

PubMed Abstract | Publisher Full Text | Free Full Text

10. Bennett EM, Cramer W, Begossi A, et al:: Linking biodiversity, ecosystem services, and human well-being: three challenges for designing research for sustainability. Curr Opin Environ Sustainability. 2015; 14: 76-85. Publisher Full Text

11. Marsh GP: Man and Nature: Or, Physical Geography as Modified by Human Action. New York: Scribner \& co. 1864; 593. Reference Source

12. Ponting C: A new green history of the world: The environment and the collapse of great civilizations. Penguin Books, 2007. Reference Source

13. F Mace GM: Ecology. Whose conservation? Science. 2014; 345(6204): 1558-60. PubMed Abstract | Publisher Full Text | F1000 Recommendation

14. Ehrlich PR, Ehrlich AH: Extinction: the causes and consequences of the disappearance of species. Random House, New York, 1981. Reference Source
15. Study of Critical Environmental Problems (SCEP): Man and the Global Environment. Cambridge, Mass: MIT Press, (Cited in Mooney, Ehrlich \& Daily 1997.). 1970.

16. Mooney HA, Ehrlich PR, Daily GE: Ecosystem services: a fragmentary history. Nature's Services: societal dependence on natural ecosystems. 1997; 11-19. Reference Source

17. Schulze ED, Mooney HA: Ecosystem function of biodiversity: a summary. In Biodiversity and ecosystem function. Springer Berlin Heidelberg, 1994; 497-510. Publisher Full Text

18. Crocker TD, Tschirhart J: Ecosystems, externalities, and economies. Environ Resour Econ. 1992; 2(6): 551-567. Reference Source

19. Heal G: Valuing Ecosystem Services. Ecosystems. 2000; 3(1): 24-30. Publisher Full Text

20. Carpenter SR, Biggs R: Freshwaters: managing across scales in space and time. In: Principles of Ecosystem Stewardship: Resilience-Based Natural Resource Management in a Changing World. FS Chapin III, GP Kofinas, and C Folke, Eds. Springer, New York, 2009; 197-220. Publisher Full Text

21. Folke $\mathrm{C}$, Carpenter SR, Walker $\mathrm{BH}$, et al:: Resilience thinking: integrating resilience, adaptability and transformability. Ecol Soc. 2010; 15(4): 20. Reference Source

22. Gunderson LH, Holling CS: Panarchy: Understanding transformations in human and natural systems. Island Press, 2002 Reference Source

23. Millennium Ecosystem Assessment: Ecosystems and Human Well-being: A Framework for Assessment. Washington, DC: Island Press, 2003. Reference Source

24. http://www.unep.org/maweb/en/History.aspx. Accessed August 4, 2016.

25. Haines-Young R, Potschin M: The links between biodiversity, ecosystem services and human well-being. Ch 6. In: Raffaelli D, Frid C. (Eds.), Ecosystem Ecology: A New Synthesis. BES Ecological Reviews Series, CUP, Cambridge, in press, 2010. Reference Source

26. Reyers B, Biggs R, Cumming GS, et al:: Getting the measure of ecosystem services: A social-ecological approach. Front Ecol Environ. 2013; 11(5): 268-73. Publisher Full Text

27. Daily GC, Polasky S, Goldstein J, et al:: Ecosystem services in decision making: Time to deliver. Front Ecol Environ. 2009; 7(1): 21-8. Publisher Full Text

28. F Fisher B, Turner RK, Morling P: Defining and classifying ecosystem services for decision making. Ecol Econ. 2009; 68(3): 643-53. Publisher Full Text | F1000 Recommendation

29. F Liu J, Yang W, Li S: Framing ecosystem services in the telecoupled Anthropocene. Front Ecol Environ. 2016; 14(1): 27-36. Publisher Full Text | F1000 Recommendation 
30. TEEB-The Economics of Ecosystems and Biodiversity: TEEB for Local and Regional Policy Makers. 2010.

Reference Source

31. Lele S, Springate-Baginski O, Lakerveld R, et al.: Ecosystem Services: Origins, Contributions, Pitfalls, and Alternatives. Conservat Soc. 2013; 11(4): 343-358. Publisher Full Text

32. F Chan KM, Shaw MR, Cameron DR, et al.: Conservation planning for ecosystem services. PLoS Biol. 2006; 4(11): e379.

PubMed Abstract | Publisher Full Text | Free Full Text | F1000 Recommendation

33. F Naidoo R, Balmford A, Costanza R, et al.: Global mapping of ecosystem services and conservation priorities. Proc Natl Acad Sci U S A. 2008; 105(28) 9495-500.

PubMed Abstract | Publisher Full Text | Free Full Text | F1000 Recommendation

34. Nelson E, Mendoza G, Regetz J, et al:: Modeling multiple ecosystem services, biodiversity conservation, commodity production, and tradeoffs at landscape scales. Front Ecol Environ. 2009; 7(1): 4-11.

Publisher Full Tex

35. Ricketts $\mathrm{TH}$, Watson KB, Koh I, et al.: Disaggregating the evidence linking biodiversity and ecosystem services. Nat Comm. 2016; 7: 13106. PubMed Abstract | Publisher Full Text

36. Bennett EM, Peterson GD, Gordon LJ: Understanding relationships among multiple ecosystem services. Ecol Lett. 2009; 12(12): 1394-404. PubMed Abstract | Publisher Full Text

37. F Bateman IJ, Harwood AR, Mace GM, et al:: Bringing ecosystem services into economic decision-making: land use in the United Kingdom. Science. 2013; 341(6141): 45-50

PubMed Abstract | Publisher Full Text | F1000 Recommendation

38. F Qiu J, Turner MG: Spatial interactions among ecosystem services in an urbanizing agricultural watershed. Proc Natl Acad Sci U S A. 2013; 110(29): 12149-54

PubMed Abstract | Publisher Full Text | Free Full Text | F1000 Recommendation

39. F Queiroz C, Meacham M, Richter K, et al.: Mapping bundles of ecosystem services reveals distinct types of multifunctionality within a Swedish landscape. Ambio. 2015; 44(Suppl 1): S89-101.

PubMed Abstract | Publisher Full Text | Free Full Text | F1000 Recommendation

40. $\mathrm{F}$ Lavorel S, Grigulis K, Lamarque $\mathrm{P}$, et al.: Using plant functional traits to understand the landscape distribution of multiple ecosystem services. $J$ Ecol. 2011; 99(1): 135-47.

Publisher Full Text | F1000 Recommendation

41. F Raudsepp-Hearne C, Peterson GD, Bennett EM: Ecosystem service bundles for analyzing tradeoffs in diverse landscapes. Proc Natl Acad Sci U S A. 2010; 107(11): 5242-7.

PubMed Abstract | Publisher Full Text | Free Full Text | F1000 Recommendation

42. Maes J, Paracchini ML, Zulian G, et al:: Synergies and trade-offs between ecosystem service supply, biodiversity, and habitat conservation status in Europe. Biol Conserv. 2012; 155: 1-12.

Publisher Full Text

43. F Martín-López B, Iniesta-Arandia I, García-Llorente M, et al:: Uncovering ecosystem service bundles through social preferences. PLoS One. 2012; 7(6) e38970.

PubMed Abstract | Publisher Full Text | Free Full Text | F1000 Recommendation

44. Plieninger T, Dijks S, Oteros-Rozas E, et al.: Assessing, mapping, and quantifying cultural ecosystem services at community level. Land Use Policy. 2013; 33: $118-29$

Publisher Full Text

45. F Andersson E, Nykvist B, Malinga R, et al:: A social-ecological analysis of ecosystem services in two different farming systems. Ambio. 2015; 44(Suppl 1): S102-12.

PubMed Abstract | Publisher Full Text | Free Full Text | F1000 Recommendation

46. F Mouchet MA, Lamarque P, Martín-López B, et al:: An interdisciplinary methodological guide for quantifying associations between ecosystem services. Global Environ Change. 2014; 28: 298-308.

Publisher Full Text | F1000 Recommendation

47. Villamagna AM, Angermeier PL, Bennett EM: Capacity, pressure, demand, and flow: A conceptual framework for analyzing ecosystem service provision and delivery. Ecol Complex. 2013; 15: 114-21.

Publisher Full Text

48. Mitchell MGE, Bennett EM, Gonzalez A, et al:: The Montérégie Connection: Linking landscapes, biodiversity, and ecosystem services to improve decision making. Ecol Soc. 2015; 20(4): 15

Publisher Full Text

49. Mitchell MGE, Bennett EM, Gonzalez A, et al:: Forest fragments modulate the provision of multiple ecosystem services. J Appl Ecol. 2014; 51(4): 909-18. Publisher Full Tex

50. Kennedy CM, Lonsdorf E, Neel MC, et al:: A global quantitative synthesis of local and landscape effects on wild bee pollinators in agroecosystems. Ecol Lett. 2013; 16(5): 584-99.

PubMed Abstract | Publisher Full Text

51. Rusch A, Chaplin-Kramer R, Gardiner MM, et al:: Agricultural landscape simplification reduces natural pest control: A quantitative synthesis. Agr Ecosyst Environ. 2016; 221: 198-204.

Publisher Full Text

52. Chaplin-Kramer R, O'Rourke ME, Blitzer EJ, et al:: A meta-analysis of crop pest and natural enemy response to landscape complexity. Ecol Lett. 2011; 14(9): 922-32.

PubMed Abstract | Publisher Full Text

53. Chaplin-Kramer R, Ramler I, Sharp R, et al.: Degradation in carbon stocks near tropical forest edges. Nat Commun. 2015; 6: 10158.

PubMed Abstract | Publisher Full Text | Free Full Text

54. Ziter C, Bennett EM, Gonzalez A: Temperate forest fragments maintain aboveground carbon stocks out to the forest edge despite changes in community composition. Oecologia. 2014; 176(3): 893-902.

PubMed Abstract | Publisher Full Text

55. Chaplin-Kramer R, Hamel P, Sharp R, et al.: Landscape configuration is the primary driver of impacts on water quality associated with agricultural expansion. Environ Res Lett. 2016; 11(7): 74012 Publisher Full Text

56. F Renard D, Rhemtulla JM, Bennett EM: Historical dynamics in ecosystem service bundles. Proc Natl Acad Sci U S A. 2015; 112(43): 13411-6. PubMed Abstract | Publisher Full Text | Free Full Text | F1000 Recommendation

57. F Oteros-Rozas E, Martín-López B, Daw TM, et al:: Participatory scenario planning in place-based social-ecological research: Insights and experiences from 23 case studies. Ecol Soc. 2015; 20(4): 32

Publisher Full Text | F1000 Recommendation

58. Fisher B, Lewis SL, Burgess ND, et al:: Implementation and opportunity costs of reducing deforestation and forest degradation in Tanzania. Nat Clim Chang. 2011; 1: 161-4.

Publisher Full Text

59. F Fisher B, Turner K, Zylstra M, et al.: Ecosystem services and economic theory: integration for policy-relevant research. Ecol Appl. 2008; 18(8): 2050-67. PubMed Abstract | Publisher Full Text | F1000 Recommendation

60. Rieb JT, Chaplin-Kramer R, Daily GC, et al.: When, where, and how much does nature matter? In Review.

61. F Hamann M, Biggs R, Reyers B: Mapping social-ecological systems: dentifying 'green-loop' and 'red-loop' dynamics based on characteristic bundles of ecosystem service use. Global Environ Chang. 2015; 34: 218-26. Publisher Full Text | F1000 Recommendation

62. Future Earth: Future Earth Strategic Research Agenda. Paris: International Council for Science (ICSU); 2014.

Reference Source

63. Cundill G, Fabricius C: Monitoring in adaptive co-management: Toward a learning based approach. J Environ Manage. 2009; 90(11): 3205-11. PubMed Abstract | Publisher Full Text

64. Cundill G, Leitch AM, Schultz L, et al: Chapter 7: Principle 5-Encourage Learning. In Principles for Building Resilience: Sustaining Ecosystem Services in Social-Ecological Systems. Eds R Biggs, M Schluter, and ML Schoon. Cambridge University Press; 2015 Publisher Full Text

65. F Yang W, Dietz T, Kramer DB, et al.: An integrated approach to understanding the linkages between ecosystem services and human wellbeing. Ecosyst Health Sustain. 2015; 1(5): 1-12 Publisher Full Text | F1000 Recommendation

66. F Yang W, Dietz T, Liu W, et al:: Going beyond the Millennium Ecosystem Assessment: an index system of human dependence on ecosystem services. PLoS One. 2013; 8(5):e64581.

PubMed Abstract | Publisher Full Text | Free Full Text | F1000 Recommendation

67. F Steffen W, Richardson K, Rockström J, et al:: Sustainability. Planetary boundaries: guiding human development on a changing planet. Science. 2015; 347(6223): 1259855

PubMed Abstract | Publisher Full Text | F1000 Recommendation

68. F Gordon LJ, Peterson GD, Bennett EM: Agricultural modifications of hydrological flows create ecological surprises. Trends Ecol Evol. 2008; 23(4): 211-9.

PubMed Abstract | Publisher Full Text | F1000 Recommendation

69. Biggs R, Schlüter M, Biggs D, et al:: Toward Principles for Enhancing the Resilience of Ecosystem Services. Annu Rev Environ Resour. 2012; 37: 421-48. Publisher Full Text

70. F Ouyang $\mathrm{Z}$, Zheng $\mathrm{H}$, Xiao $\mathrm{Y}$, et al:: Improvements in ecosystem services from investments in natural capital. Science. 2016; 352(6292): 1455-9. PubMed Abstract | Publisher Full Text | F1000 Recommendation

71. Egoh B, Reyers B, Rouget M, et al:: Mapping ecosystem services for planning and management. Agr Ecosyst Environ. 2008; 127(1-2): 135-40. Publisher Full Text

72. Reyers B, Polasky S, Tallis H, et al:: Finding Common Ground for Biodiversity and Ecosystem Services. BioScience. 2012; 62(5): 503-7. Publisher Full Text

73. Donovan S, Goldfuss C, Holdren J: Memorandum for executive departments and 
agencies M-16-01 "Incorporating ecosystem services into federal decision making. Issued 72015.

Reference Source

74. F Kremen C: Managing ecosystem services: what do we need to know about their ecology? Ecol Lett. 2005; 8(5): 468-79.

PubMed Abstract | Publisher Full Text | F1000 Recommendation

75. Bennett EM: Research frontiers in ecosystem service science. Ecosystems. 2016; $1-7$

Publisher Full Text

76. Liss KN, Mitchell MGE, MacDonald GK, et al:: Variability in ecosystem service measurement: A pollination service case study. Front Ecol Environ. 2013; 11(8): 414-22.

Publisher Full Text

77. Kirchhoff CJ, Carmen Lemos M, Dessai S: Actionable Knowledge for Environmental Decision Making: Broadening the Usability of Climate Science. Annu Rev Environ Resour. 2013; 38: 393-414.

Publisher Full Text

78. Braat LC, de Groot R: The ecosystem services agenda: Bridging the worlds of natural science and economics, conservation and development, and public and private policy. Ecosyst Serv. 2012; 1(1): 4-15. Publisher Full Text

79. F Posner SM, McKenzie E, Ricketts TH: Policy impacts of ecosystem service knowledge. Proc Natl Acad Sci U S A. 2016; 113(7): 1760-5. PubMed Abstract | Publisher Full Text | Free Full Text | F1000 Recommendation

80. F Martinez-Harms MJ, Bryan BA, Balvanera $P$, et al:: Making decisions for managing ecosystem services. Biol Conserv. 2015; 184: 229-38. Publisher Full Text | F1000 Recommendation

81. Matson P, Clark WC, Andersson K: Pursuing Sustainability: A Guide to the Science and Practice. Princeton University Press, 2016; 248 Reference Source

82. Norgaard RB: Finding hope in the millennium ecosystem assessment. Conserv Biol. 2008; 22(4): 862-9.

PubMed Abstract | Publisher Full Text

83. Carpenter SR, Bennett EM, Peterson GD: Scenarios for ecosystem services: an overview. Ecol Soc. 2006; 11(1): 29. Reference Source

84. Armsworth PR, Chan KM, Daily GC, et al.: Ecosystem-service science and the way forward for conservation. Conserv Biol. 2007; 21(6): 1383-4. PubMed Abstract | Publisher Full Text

85. Muradian R, Corbera E, Pascual U, et al:: Reconciling theory and practice: An alternative conceptual framework for understanding payments fo environmental services. Ecol Econ. 2010; 69(6): 1202-8. Publisher Full Text

86. F Ruckelshaus $M$, McKenzie $\mathrm{E}$, Tallis $\mathrm{H}$, et al: Notes from the field: Lessons learned from using ecosystem service approaches to inform real-world decisions. Ecol Econ. 2015; 115: 11-21. Publisher Full Text | F1000 Recommendation

87. Villa F, Bagstad KJ, Voigt B, et al:: A methodology for adaptable and robust ecosystem services assessment. PLoS One. 2014; 9(3): e91001. PubMed Abstract | Publisher Full Text | Free Full Text

88. Jackson B, Pagella T, Sinclair F, et al:: Polyscape: A GIS mapping framework providing efficient and spatially explicit landscape-scale valuation of multiple ecosystem services. Landsc Urban Plan. 2013; 112: 74-88. Publisher Full Text

89. Mulligan M: WaterWorld: A self-parameterising, physically based model for application in data-poor but problem-rich environments globally. Hydrol Res. 2013; 44(5): 748-769.

Publisher Full Text

90. Bagstad KJ, Semmens DJ, Waage S, et al.: A comparative assessment of decision-support tools for ecosystem services quantification and valuation. Ecosyst Serv. 2013; 5: 27-39.

Publisher Full Text

91. F Ekroos J, Olsson O, Rundlöf $\mathrm{M}$, et al.: Optimizing agri-environment schemes for biodiversity, ecosystem services or both? Biol Conserv. 2014; 172 65-71. Publisher Full Text | F1000 Recommendation

92. Jang T, Vellidis G, Hyman JB, et al:: Model for prioritizing best management practice implementation: sediment load reduction. Environ Manage. 2013; 51(1): 209-24.

PubMed Abstract | Publisher Full Text | Free Full Text

93. Trabucchi M, Ntshotsho P, O'Farrell P, et al.: Ecosystem service trends in basinscale restoration initiatives: a review. J Environ Manage. 2012; 111: 18-23. PubMed Abstract | Publisher Full Text

94. F Mandle L, Tallis H, Sotomayor L, et al.: Who loses?: Tracking ecosystem service redistribution from road development and mitigation in the Peruvian Amazon. Front Ecol Environ. 2015; 13(6): 309-15. Publisher Full Text | F1000 Recommendation

95. F Arkema KK, Guannel G, Verutes G, et al:: Coastal habitats shield people and property from sea-level rise and storms. Nat Clim Chang. 2013; 3: 913-8.

Publisher Full Text | F1000 Recommendation

96. Walters C: Adaptive management of renewable resources. MacMillan Publishers: New York; 1986. Reference Source

97. Armitage DR, Plummer R, Berkes F, et al:: Adaptive co-management for socialecological complexity. Front Ecol Environ. 2009; 7(2): 95-102. Publisher Full Text

98. Dearing JA, Yang $X$, Dong $X$, et al: Extending the timescale and range of ecosystem services through paleoenvironmental analyses, exemplified in the lower Yangtze basin. Proc Natl Acad Sci U S A. 2012; 109(18)

E1111-20.

PubMed Abstract | Publisher Full Text | Free Full Text

99. Tomscha S, Sutherland I, Renard D, et al.: A guide to historical data sets for reconstructing ecosystem service change over time. BioScience. 2016; 66(9): 947-762. Publisher Full Text

100. Foster D, Swanson F, Aber J, et al:: The Importance of Land-Use Legacies to Ecology and Conservation. BioScience. 2003; 53(1): 77-88. Publisher Full Text

101. Meyfroidt $P$, Lambin EF, Erb K, et al:: Globalization of land use: Distant drivers of land change and geographic displacement of land use. Curr Opin Environ Sustain 2013: 5(5): 438-44. Publisher Full Text

102. F Liu J, Hull V, Batistella M, et al.: Framing Sustainability in a Telecoupled World. Ecol Soc. 2013; 18(2): 26. Publisher Full Text | F1000 Recommendation

103. Leitch AM, Cundill G, Schultz L, et al.: Chapter 8: Principle 6-Broaden Participation. In Principles for Building Resilience: Sustaining Ecosystem Services in Social-Ecological Systems. Eds R Biggs, M Schluter, and ML Schoon. Cambridge University Press; 2015

Reference Source 


\section{Open Peer Review}

\section{Current Peer Review Status:}

\section{Editorial Note on the Review Process}

Faculty Reviews are review articles written by the prestigious Members of Faculty Opinions. The articles are commissioned and peer reviewed before publication to ensure that the final, published version is comprehensive and accessible. The reviewers who approved the final version are listed with their names and affiliations.

\section{The reviewers who approved this article are:}

\section{Version 1}

\section{Liu Jianguo}

Center for Systems Integration and Sustainability, Department of Fisheries and Wildlife, Michigan State University, East Lansing, MI, USA

Competing Interests: No competing interests were disclosed.

\section{Brendan Fischer}

Gund Institute for Ecological Economics, Rubenstein School of Environment and Natural Resources, University of Vermont, Burlington, VT, USA

Competing Interests: No competing interests were disclosed.

The benefits of publishing with F1000Research:

- Your article is published within days, with no editorial bias

- You can publish traditional articles, null/negative results, case reports, data notes and more

- The peer review process is transparent and collaborative

- Your article is indexed in PubMed after passing peer review

- Dedicated customer support at every stage

For pre-submission enquiries, contact research@f1000.com 